\title{
Cholinesterase Activities and Oxidative Stress in Cattle Experimentally Exposed to Nitrate/Nitrite in Cultivated Pasture with Different Fertilization Schemes
}

\author{
Ricardo Christ', Aleksandro Schafer Da Silva ${ }^{2}$, Mateus Eloir Gabriel', Luan Cleber Henker ${ }^{1}$, Renan Augusto Cechin ${ }^{1}$, \\ Manoela Marchezan Piva', Nathieli Bianchin Bottari ${ }^{3}$, Maria Rosa Chitolina Schetinger ${ }^{3}$, \\ Matheus Pedrotti De Cesaro" ${ }^{4}$ Vera Maria Morsch ${ }^{3} \&$ Ricardo Evandro Mendes'
}

\begin{abstract}
Background: Nitrate and nitrite poisoning is associated with pasture intake that has high nitrate levels and leads to acute methemoglobinemia. Pasture may accumulate nitrate under certain conditions, such as excessively fertilized soil or environmental conditions that enhance the $\mathrm{N}$ absorption (rain preceded by a period of drought). After ingestion of plants, this substrate reaches the rumen and, in physiological conditions, is reduced to nitrite and afterward to ammonia. The aim of this study was to evaluate changes in cholinesterase activities and oxidative stress caused by subclinical poisoning for nitrate and nitrite in cattle fed with Pennisetum glaucum in three different fertilization schemes.

Materials, Methods \& Results: In order to perform the experimental poisoning, the pasture was cultivated in three different paddocks: with nitrogen topdressing (urea; group 1), organic fertilizer (group 2) or without fertilizer (group 3; control). Nitrate accumulation in forage was evaluated by the diphenylamine test. After food fasting of $12 \mathrm{~h}$, nine bovine were randomly allocated to one of the experimental groups and fed with fresh forage (ad libitum) from respective paddock. In different time points from beginning of pasture intake $(0,2,4,6$ and $9 \mathrm{~h})$ heart rate and respiratory frequency were assessed, as well as mucous membrane color and behavioral changes. Blood samples from jugular vein into vials with and without anticoagulant were collected. From blood samples, serum nitrite levels, acetylcholinesterase (AChE) and butyrylcholinesterase (BChE) enzyme activity were evaluated, as well as oxidative stress through the following parameters: levels of nitrate/nitrite $\left(\mathrm{NO}_{x}\right)$, thiobarbituric acid reactive substances (TBARS) and reactive oxygen species (ROS), beyond the antioxidant system by enzyme activity measurement of catalase (CAT) and superoxide dismutase (SOD). The diphenylamine test was positive to group 1 and 2 , so that the pasture presented $3.16 \mathrm{mg} / \mathrm{kg}, 2.98 \mathrm{mg} / \mathrm{kg}$ and $1.67 \mathrm{mg} / \mathrm{kg}$ of nitrate for group 1, 2 and 3, respectively. In addition, cows from group 1 demonstrated increased $(P<0.05)$ nitrite levels in serum, compared to other groups, and greater heart rate after $9 \mathrm{~h}(P<0.05)$. The AChE and BChE activity in group 1 showed significant increase $(P<0.05)$ at 4 and $6 \mathrm{~h}(\mathrm{AChE})$, and 4 and $9 \mathrm{~h}(\mathrm{BChE})$ compared to group 3 . Also, NOx levels were lower at 6 and $9 \mathrm{~h}(P<0.05)$ and at $9 \mathrm{~h}(P<0.05)$ for animals of group 1 and 2, respectively, when compared to group 3. Furthermore, in the group 1 levels of ROS and TBARS were significantly higher $(P<0.05)$ after 2 and $4 \mathrm{~h}$, and 6 and $9 \mathrm{~h}$ compared to other groups, respectively. The CAT activity increased significantly $(P<0.05)$ with 2 and $4 \mathrm{~h}$ of the experiment, but on the other hand, decreased at 6 and $9 \mathrm{~h}$ in group 1 . Nevertheless, the animals from group 2 presented only a significant reduction in this enzyme activity at $9 \mathrm{~h}$. Furthermore, SOD activity was reduced in animals of groups 1 $(P<0.05)$ at 4,6 and $9 \mathrm{~h}$, compared to other groups.

Discussion: It was concluded that the nitrate and nitrite poisoning by pasture intake cultivated and fertilized with urea leads to increased levels of serum nitrite, as well as the cholinesterase activity and causes oxidative stress in cattle. It is conjectured that the cholinesterase activity and oxidative stress may assist in understanding the pathophysiology of changes caused by poisoning.
\end{abstract}

Keywords: plant toxicology, poisoning, methemoglobin, cholinergic system, oxidative stress.

DOI: $10.22456 / 1679-9216.82068$

${ }^{1}$ Laboratory of Veterinary Pathology, Instituto Federal Catarinense (IFC), Concórdia, SC, Brazil. ${ }^{2}$ Animal Science Graduate Program, Universidade do Estado de Santa Catarina (UDESC), Chapecó, SC. ${ }^{3}$ Department of Biochemistry and Molecular Biology and Department of Microbiology and Parasitology \& ${ }^{4}$ Faculty of Veterinary Medicine, Meridional Institute (IMED), Passo Fundo, RS, Brazil.CORRESPONDENCE: R.E. Mendes [ricardo.mendes@ifc. edu.br - Tel.: +55 (49) 3441-4818]. Laboratory of Veterinary Pathology, Instituto Federal Catarinense (IFC). Rod. SC 283 s/n. Km 17. Bairro Fragosos. CP 58. CEP 89703-720 Concórdia, SC, Brazil. 


\section{INTRODUCTION}

Nitrate/nitrite poisoning is usually associated with mortality of cattle introduced in pastures with high nitrate levels [33]. Under normal conditions, pasture absorbs nitrogen in the soil and converts it into plant material, however, under favorable conditions such as excessively fertilized soil or environmental conditions that enhance the $\mathrm{N}$ absorption (rain preceded by a period of drought), nitrate $\left(\mathrm{NO}_{3}\right)$ accumulation in the pasture with toxic potential when ingested in sufficient quantities could occur [17,22,33]. After ingestion of plants with high $\mathrm{NO}_{3}$ levels, this substrate reaches the rumen and, in physiological conditions, is reduced to nitrite $\left(\mathrm{NO}_{2}\right)$ and afterward to ammonia $\left(\mathrm{NH}_{3}\right)$. When $\mathrm{NO}_{3}$ is ingested in large quantities, its reduction into $\mathrm{NH}_{3}$ is not efficient and $\mathrm{NO}_{2}$ accumulates in the rumen, which is absorbed into the circulatory system [19]. In the bloodstream, $\mathrm{NO}_{2}$ oxidizes the iron ion of hemoglobin from ferrous $\left(\mathrm{Fe}^{+2}\right)$ state to ferric $\left(\mathrm{Fe}^{+3}\right)$, reducing the hemoglobin to methemoglobin that is unable to carry oxygen to the tissue [33]. Therefore, these changes may affect other system as the cholinergic, involved in several physiological functions of the organism.

Oxidative stress was already described in clinical poisoning by plants with high levels of nitrate and nitrite [2] and by Senecio sp. [4]. However, in most cases the poisoning is subclinical, not identified by farmers, which may cause production losses. Therefore, the aims of this study were to evaluate the cholinesterase activities and the status of oxidative stress in cattle fed with Pennisetum glaucum cultivated in three different fertilizer schemes, targeting the subclinical poisoning by nitrate/nitrite.

\section{MATERIALS AND METHODS}

\section{Experimental design}

The cultivation of Pennisetum glaucum (pearl millet) was performed in approximately $600 \mathrm{~m}^{2}$ area, with $50 \mathrm{~kg}$ of seeds per hectare (ha), divided into three paddocks of equal proportions and with individualized fertilization. In the paddock 1 nitrogen topdressing (urea $45 \%$ ) was performed at ratio of $150 \mathrm{~kg} / \mathrm{ha}$, fifteen days before de experiment; the paddock 2 received organic fertilizer (swine and cattle manure) at dose of $5 \mathrm{t} / \mathrm{ha}$, thirty and fifteen days before de experiment; and the paddock 3, used as control, received no fertilizer of any kind. When de pasture reached the cutoff point the diphenylamine test to evaluate nitrate accumulation was conducted. Briefly, $0.5 \mathrm{~g}$ of diphenylamine were diluted in $20 \mathrm{~mL}$ of distilled water plus sulfuric acid until $100 \mathrm{~mL}$, to form the diphenylamine reagent. The test consists of obtaining a few drops of vegetable extract placed on glass slide with addition of 2-3 drops of diphenylamine ${ }^{1}$ reagent. The reaction is considered positive when in less than 10 seconds form an intense blue staining [14].

Nine male bovine, Holstein breed, aged about 12 months, body weight medium of $200 \mathrm{~kg}$, were used in the experiment. After food fasting of $12 \mathrm{~h} \mathrm{(ad} \mathrm{libi-}$ tum access to water), animals were randomly allocated in three groups ( $\mathrm{n}=3$ bovine/group). For each group fresh pasture from respective paddock in individual feeders (Table 1) was provided once, ad libitum, for 3 h. During the experiment (under resting state) heart rate and respiratory frequency (auscultation), mucous membranes color (visual evaluation) and possible behavioral changes, besides the quantity of pasture intake were evaluated. All evaluations were performed at hour zero, two, four, six and nine after beginning pasture intake.

Table 1. Pasture intake and nitrate levels in different groups.

\begin{tabular}{cccc}
\hline & Grup 1 & Grup 2 & Grup 3 \\
\cline { 2 - 4 } Fertilizer & Urea & Manure & Control \\
\hline Average Body weigth $(\mathrm{kg})$ & 244 & 254 & 172 \\
Pasture intake/animal $(\mathrm{kg})$ & 9.33 & 11.33 & 3.9 \\
Pasture intake/ & 3.71 & 4.70 & 2.36 \\
body weigth $(\%)$ & & & \\
Dyphenylamine & +++ & + & - \\
Pasture nitrate $(\mathrm{mg} / \mathrm{kg})$ & 3.16 & 2.98 & 1.67 \\
\hline
\end{tabular}

*Dyphenylamine test: (+++) Strong positive reaction; (+) Positive reaction; (-) Negative Reaction.

At the same time points after beginning pasture intake $(0,2,4,6$ and $9 \mathrm{~h})$ blood samples were collected from jugular vein into three vials containing EDTA, sodium citrate or without anticoagulant. The blood from vials without anticoagulant were kept at room temperature after collection until blood clotting and centrifuged at $16000 \mathrm{~g}$ for $10 \mathrm{~min}$ to obtain the serum, which was properly stored at $-20^{\circ} \mathrm{C}$ for analysis of nitrite, ROS, TBARS, BChE and NOx. The blood in sodium citrate was stored at $-20^{\circ} \mathrm{C}$ until analysis of CAT and SOD. Likewise, the blood with EDTA was homogenized in hemolytic buffer (1:50) and frozen $\left(-20^{\circ} \mathrm{C}\right)$ for $\mathrm{AChE}$ analysis. 


\section{Biochemical analysis}

Nitrite was measured by spectrophotometric method using diazotization of sulfanilic acid with nitrite ion coupled with (naphthyl)ethylenediamine ${ }^{1}$, generating a measurable pink metabolite with absorbance measured at $540 \mathrm{~nm}$ [11]. For this, $300 \mathrm{uL}$ of serum was used and the results expressed in $\mathrm{mmol} / \mathrm{mL}$.

For determination of $\mathrm{NO}_{x}$, a serum aliquot $(200$ $\mathrm{uL}$ ) was homogenized in $200 \mathrm{mM} \mathrm{Zn}_{2} \mathrm{SO}_{4}$ and acetonitrile $^{1}$. Then, the solution was centrifuged at $16.000 \mathrm{~g}$ for $30 \mathrm{~min}$ at $4{ }^{\circ} \mathrm{C}$ and the supernatant was collected for analysis of the $\mathrm{NO}_{\mathrm{x}}$ levels as previously described [24]. $\mathrm{NO}_{\mathrm{x}}$ was determined by $570 \mathrm{~nm}$ absorbance technique and the results expressed in $\mu \mathrm{mol} / \mathrm{mg}$ protein.

Oxidative profile was determined using two biochemical techniques, which aims to measure levels of TBARS and ROS. TBARS was used to determine lipid peroxidation in serum samples, as described [16]. The methodology used spectrophotometry $(535 \mathrm{~nm})$ and results were expressed as nmol of malondialdehyde ${ }^{1}$ (MDA) per mL. To determinate ROS levels, serum samples were prepared as described [1], and thereafter, the serum was diluted (1:10) with $10 \mathrm{nM}$ Tris ( $\mathrm{pH} 7.4)$ and $5 \mathrm{uL}$ of 2', 7'-dichlorofluorescein diacetate 1 (DCFHDA) was added in methanol at $37^{\circ} \mathrm{C}$ in $5 \% \mathrm{CO}_{2}$ for 15 min, enough time to esterase form a non-fluorescent compound (2',7'dichlorofluorescein - (DCFH(2)) [3]. The ROS formation was quantitated from the standard curve of DCF in methanol $(0.05-1.0 \mathrm{mM})$, and the results were expressed as U DCF/mg protein.

The antioxidant status was assessed by analysis of CAT and SOD enzyme activities using spectrophotometry. The determination of CAT activity was performed according to the modified method [29], using $0.02 \mathrm{~mL}$ of blood aliquot (diluted 1:10 with saline solution) and homogenized in $0.910 \mathrm{~mL}$ potassium phosphate buffer ${ }^{1}$ at $50 \mathrm{mM}$ and $\mathrm{pH} 7.0$. Whereas the measurement of SOD activity was based on inhibition of superoxide radical reaction with epinephrine, as described [21]. The CAT and SOD results were expressed in nmol CAD per mg protein and IU of SOD per mg protein, respectively.

The cholinesterase was measured in whole blood (AChE) and serum (BChE). Enzymatic analysis of AChE in whole blood was determined [36], which aims to determine the specific activity of AChE in whole blood from the quotient between the AChE activity and hemoglobin content. The determination of BChE activity in serum followed the method [9] using the substrate butirilcolina ${ }^{1}$. The results of $\mathrm{AChE}$ and $\mathrm{BChE}$ were presented in $\mathrm{mU} / \mathrm{L}$ molHb and $\mu$ moles of $\mathrm{BcSCh} / \mathrm{h}$ per mg protein, respectively.

\section{Statistical analysis}

Relative data for the evaluated parameters of AChE, BChE, NO , ROS, TBARS, CAT and SOD were initially analyzed using descriptive statistics for contingency of information and to obtain new hypotheses, being presented as mean and standard deviation. Data were tested for normality of variance through the Shapiro-Wilk test, for asymmetry, and homogeneity by the Levene test, prior the analysis. One-way ANOVA was used to analyze all the above mentioned parameters and compared the average between groups in each time point $(0,2,4,6$, and $9 \mathrm{~h}$ of the experiment), followed by Tukey test. Values were considered different significantly at $P<0.05$. All the statistical process was carried out by R-language, v.2.15. ${ }^{2}$ (R Development Core Team) ${ }^{2}$.

The statistical analysis of heart rate and respiratory frequency was performed using SPSS 25.0 software for Macintosh OSX (IBM) ${ }^{3}$ and the Kolmogorov-Smirnov test was used to determine whether the distributions were parametric. The results between groups were compared using the Student $t$ test when the distributions were parametric and the Mann-Whitney U test for nonparametric distributions.

\section{RESULTS}

The diphenylamine test performed in the pasture paddocks was strongly positive for group 1 , moderately positive for group 2 and negative for group 3 (Figure 1). The pasture intake by animals was not enough to cause clinical poisoning, being the intake about $3.71 \%$ of live weight in group 1, $4.70 \%$ in group 2 and $2.36 \%$ in group 3. Nitrate analysis on pasture showed values of $3.16 \mathrm{mg} / \mathrm{kg}$ in group $1,2.98 \mathrm{mg} / \mathrm{kg}$ for group 2 and $1.67 \mathrm{mg} / \mathrm{kg}$ for group 3 (Table 1).

Regarding clinical parameters measured, respiratory rate did not differ between groups throughout the experiment, as well as the mucous membranes color. The heart rate was significantly different $(P<0.05)$ in the group 1 when compared with group 3 at the hour 9 of the experiment; in other words, there was an increase in heart rate of animals in group 1 . Nitrite serum dosage was significantly higher $(P<0.05)$ for group 1 when compared to group 3 , an increase of $43.56 \%, 73.33 \%$ and $78.78 \%$ at 4,6 and $9 \mathrm{~h}$, respectively. On the other hand, serum nitrite level was not significantly different $(P>0.05$; Figure 2$)$ in group 2 compared to the group 3 (Table 2). 
R. Christ, A.S. Da Silva, M.E. Gabriel, et al. 2018. Cholinesterase Activities and Oxidative Stress in Cattle Experimentally Exposed to Nitrate/Nitrite in Cultivated Pasturewith DifferentFertilization Schemes. ActaScientiae Veterinariae.46:1546.

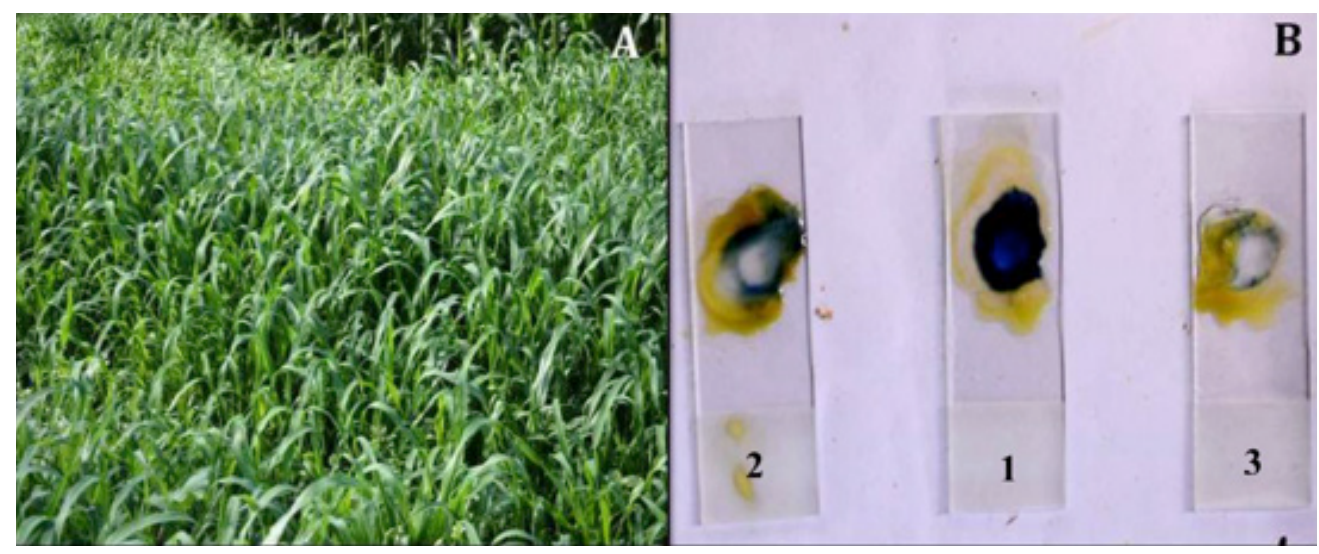

Figure 1. A- Pennisetum glaucum cultivation used in the experiment (group 1). B- diphenylamine test with strong positive reaction in the group $1(+++)$, positive in group $2(+)$ and negative in group $3(-)$ for the grazing of pickets A, B and $\mathrm{C}$, respectively. Reaction considered positive when displayed intense blue staining seconds after mixing of the reagent.

\section{Nitrite}

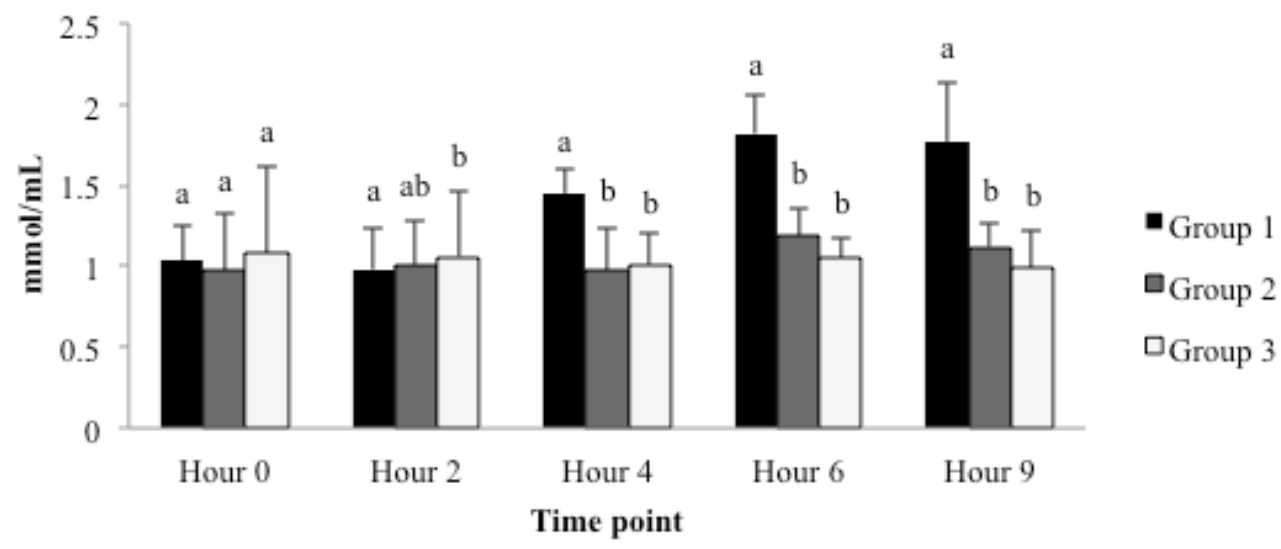

Figure 2. Mean and standard deviation of nitrite measured in cattle fed pasture fertilized with urea (group 1), organic fertilizer (group 2) and control without fertilization (group 3). Same letters in the same series show not statistical difference $(P>0.05)$.

Table 2. Respiratory and cardiac rate in different groups.

\begin{tabular}{ccccc}
\hline Parameter & Hours & \multicolumn{3}{c}{ Mean } \\
\hline Heart rate & 0 & $92.0 \pm 28.0^{\mathrm{a}}$ & $100.7 \pm 4.2^{\mathrm{a}}$ & $98.7 \pm 2.3^{\mathrm{a}}$ \\
$(\mathrm{bpm})$ & 2 & $72.7 \pm 13.3^{\mathrm{a}}$ & $89.3 \pm 10.1^{\mathrm{a}}$ & $89.3 \pm 9.2^{\mathrm{a}}$ \\
& 4 & $76.0 \pm 4.0^{\mathrm{a}}$ & $93.3 \pm 18.9^{\mathrm{a}}$ & $81.3 \pm 9.2^{\mathrm{a}}$ \\
& 6 & $81.3 \pm 10.1^{\mathrm{a}}$ & $90.7 \pm 10.1^{\mathrm{a}}$ & $80.7 \pm 22.5^{\mathrm{a}}$ \\
& 9 & $100 \pm 4.3^{\mathrm{a}}$ & $90.7 \pm 2.2^{\mathrm{b}}$ & $77.3 \pm 2.3^{\mathrm{c}}$ \\
\hline Respiratory rate & 0 & $42.7 \pm 16.8^{\mathrm{a}}$ & $67.3 \pm 27.3^{\mathrm{a}}$ & $53.3 \pm 7.6^{\mathrm{a}}$ \\
$($ mpm) & 2 & $40 \pm 17.4^{\mathrm{a}}$ & $45.3 \pm 4.6^{\mathrm{a}}$ & $36 \pm 8.0^{\mathrm{a}}$ \\
& 4 & $44.0 \pm 10.6^{\mathrm{a}}$ & $40.7 \pm 9.4^{\mathrm{a}}$ & $44 \pm 10.6^{\mathrm{a}}$ \\
& 6 & $36.0 \pm 6.9^{\mathrm{a}}$ & $42.0 \pm 7.2^{\mathrm{a}}$ & $42.0 \pm 5.3^{\mathrm{a}}$ \\
& 9 & $52.7 \pm 11.7^{\mathrm{a}}$ & $52.0 \pm 10.6^{\mathrm{a}}$ & $46.7 \pm 11.0^{\mathrm{a}}$ \\
\hline
\end{tabular}

Different letters in the same series show statistical difference $(P<0.05)$. 
The AChE activity was different $(P<0.05)$ in the group $1,100 \%$ higher at $4 \mathrm{~h}$ and $144 \%$ at $6 \mathrm{~h}$ after beginning the experiment, when compared to group 3 (Figure 3). The BChE activity was also increased at 4 and $9 \mathrm{~h}$ in group $1(P<0.05)$, being this increase of $22.3 \%$ and $50.3 \%$ when compared to group 3 . AChE and $\mathrm{BChE}$ activity in the group 2 did not present significant difference to group $3(P>0.05)$.
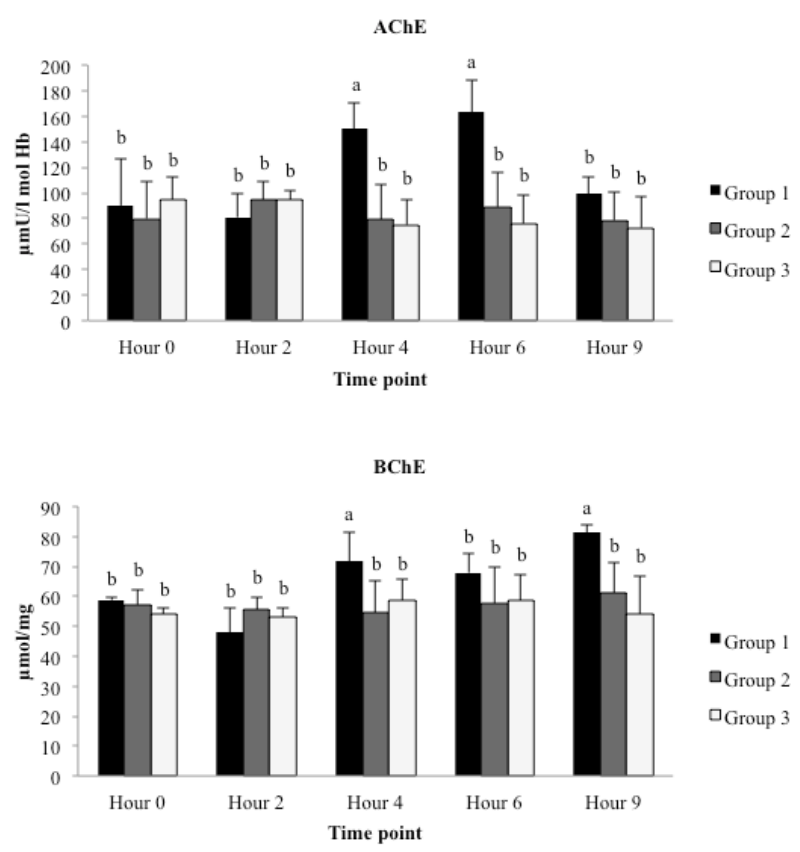

Figure 3. Mean and standard deviation of $\mathrm{AChE}$ and $\mathrm{BChE}$ activities measured in cattle fed pasture fertilized with urea (group 1), organic fertilizer (group 2) and control without fertilization (group 3). Same letters in the same series show not statistical difference $(P>0.05)$.

The $\mathrm{NO}_{x}$ values were significantly higher (48.2\%) in animals from group 1 compared to group 3 at $2 \mathrm{~h}$ of the experiment. However, with 6 and $9 \mathrm{~h}$ there was a reduction in serum $\mathrm{NO}_{x}$ levels that reached $39.41 \%$ and $77.66 \%$ when compared to group 3, respectively (Figure 4). At hour 9, a significant difference between groups 1 and 2, also as compared to the control group, was observed; with difference of $64.17 \%$ between groups 1 and 2, and $37.66 \%$ higher for group 3 than the group 2 (Figure 4). The ROS levels increased significantly in animals from group 1 compared to group 3 in 2 and $4 \mathrm{~h}$, that is, $52.20 \%$ and $40.61 \%$ higher in bovine fed with nitrogen topdressing pasture; however, with $9 \mathrm{~h}$ of experiment the ROS levels of group 1 reduced about $29.54 \%$ compared to group 3 (Figure 4). Lipid peroxidation also occurred in group 1, due an increase in TBARS levels of $31.01 \%, 66.03 \%$ and $56.88 \%$ at hours 2,6 and 9 of the experiment, respectively, when compared to group 3 (Figure 4).

Animals from group 1 showed a significant increase in CAT activity at 2 and $4 \mathrm{~h}$ of the experiment, and this difference was $55.74 \%$ and $32.29 \%$ higher, respectively, compared to group 3. However, with 6 and $9 \mathrm{~h}$ a decreased CAT activity in animals from group 1 compared to group 3 (35.74\% and $42.30 \%$, respectively) were observed. Furthermore, at hour 9 of the experiment animals from group 2 also showed lower CAT activity compared to group 3 (a decrease of $45.20 \%$; Figure 5). The SOD enzyme activity had a significant reduction in bovines from group 1 compared to group 3, and this decrease occurred at 4, 6 and 9 h, being $27.00 \%, 39.70 \%$ and $39.90 \%$, respectively (Figure 5).
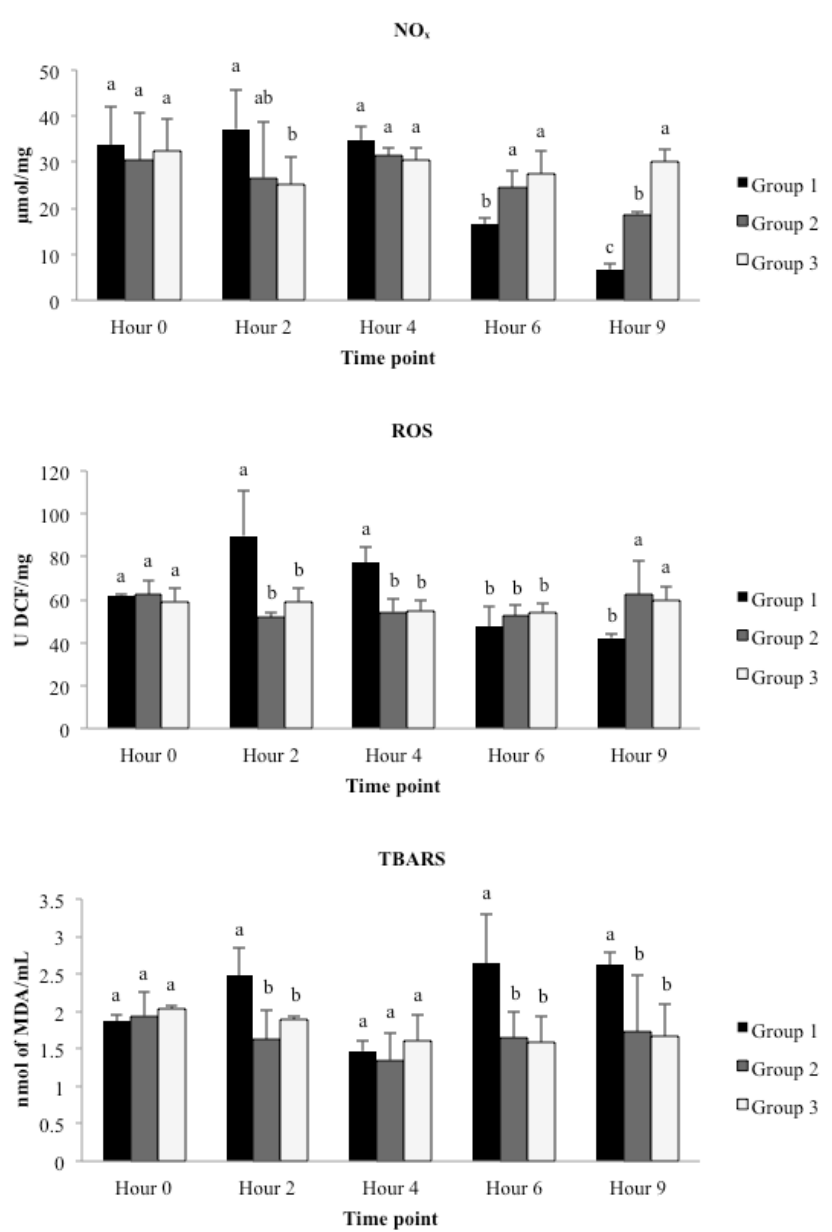

Figure 4. Mean and standard deviation of NOx, ROS and TBARS levels measured in cattle fed pasture fertilized with urea (group 1), organic fertilizer (group 2) and control without fertilization (group 3). Same letters in the same series show not statistical difference $(P>0.05)$. 

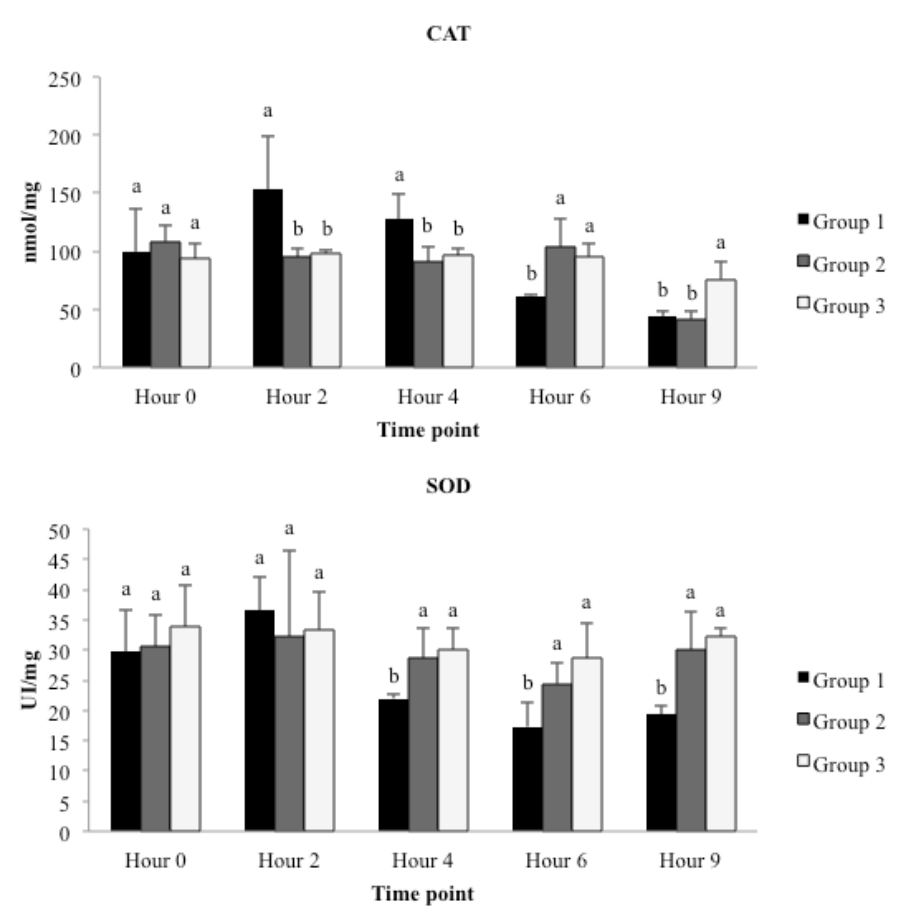

Figure 5. Mean and standard deviation of CAT and SOD levels measured in cattle fed pasture fertilized with urea (group 1), organic fertilizer (group 2) and control without fertilization (group 3). Same letters in the same series show not statistical difference $(P>0.05)$.

\section{DISCUSSION}

During the experiment none of animals presented clinical signs of poisoning by nitrate and nitrite with progressive dyspnea, cyanosis, ataxia and convulsions, according with described in literature [30,32]. However, animals of group 1 showed an increase in heart rate after $9 \mathrm{~h}$ of the experiment. Tachycardia is an important compensatory mechanism in any alteration of oxygen transport, when there is a deficient oxygenation, such as methemoglobinemia that attempts to raise the cardiac output, increasing blood pressure, heart rate and force of contraction [18,34]. Thereby, showing that even in subclinical poisoning the organism is altered to compensate the poisoning.

Regarding pasture consumption although group 3 ingested much less pasture per animal ( $3.9 \mathrm{~kg})$, the pasture intake per body weight were quite similar between groups, ranging between 2.36 and 3.71, not interfering among groups. Furthermore, group 2 (manure) ingested even more pasture than group 1 (urea).

The pasture fertilization is directly related with nitrate accumulation in plants. The excessive fertilization is reported in several outbreaks of nitrate and nitrite poisoning [17,22], being described after use of nitro- gen fertilizer [17] and also organic fertilizer, mainly from pigs and poultry [17,22]. The intense soil use, jointly with the fact that agricultural activity is linked to animal production, favors the use of organic fertilizer in the pasture. In addition, some climatic factors trigger greater absorption into the plant. Intensive rain preceded by a drought period is cited in the literature as one of the main factors to nitrate accumulation in plant [26,27]. It was mentioned [33] that pastures with nitrate levels above $1.5 \%$, or between 0.5 to $4 \%$ [26] would be potentially toxic to cattle. Also, researchers [17] evaluated several outbreaks of nitrate/nitrite poisoning and found nitrate values in the pasture ranging from 0.3 to $3.36 \%$, which agrees with levels found in this study, since a small amount of accumulated nitrate is able to induce subclinical poisoning.

One of the major consequences of nitrate/nitrite poisoning is abortion that occurs due the hypoxia generated by methemoglobinemia, inducing injuries to the fetus. Some studies have reported the occurrence of abortions in poisoned animals, treated or with spontaneous regression after few days of the poisoning $[6,17]$. The occurrence of abortions in animals that fed pasture with high nitrate levels was reported [28], but did not developed characteristic clinical symptoms 
of poisoning. This indicates that even a mild nitrate/ nitrite poisoning may lead to some fetal damage [26].

Studies with AChE and BChE enzymes showed the participation of this system in regulatory mechanisms of the organism by hypoxia, regulating the activity of the cholinergic system [5]. In nitrate and nitrite poisoning intense hydrolysis of acetylcholine due to increase of $\mathrm{AChE}$ and $\mathrm{BChE}$ activity in the synaptic cleft occurs. This mechanism appears in response to hypoxia generated by methemoglobinemia, where oxygen transport is poor. The AChE and BChE activity have parasympatholytic action, inhibiting cholinergic neurotransmission, an effect that leads the increase of vital signs in an attempt to compensate the oxygenation disorders $[15,20,23]$. The increase observed in cholinesterase activities may explain the pathophysiology of cardiac and respiratory changes, since intense degradation of acetylcholine with modulator cardiorespiratory effect occurs. This is due to inhibition of parasympathetic neurons and activation of the sympathetic pathway, mechanism activated in response to hypoxia in an effort to increase the oxygen transport to tissues.

The increase in nitrite serum levels indicates that the pasture intake in group 1 induced the ruminal conversion of nitrate to nitrite and, therefore, absorption into the bloodstream [33]. Oxidation of hemoglobin to methemoglobin occurs when nitrite reaches the bloodstream and oxidizes the iron ion of ferrous state $\left(\mathrm{Fe}^{+2}\right)$ to ferric $\left(\mathrm{Fe}^{+3}\right)$, which leads to hypoxia signs observed in group 1, characterized by increased heart rate $[17,22,34]$. Furthermore, nitrite in the bloodstream participates of the reaction catalyzed by peroxidase, especially in the presence of $\mathrm{H}_{2} \mathrm{O}_{2}$ that might lead to damage in many organic molecules, favoring cell injury as a result of the nitric oxide (NO) production [35]. It was described that high nitrite absorption, derived from plants with high $\mathrm{NO}_{3}$ levels conducts to tissue damage due to NO production [7]. This observation corroborates the results found in this study, increased levels of nitrite and NO.

The NO has selective reactivity and is able to react with other paramagnetic molecules such as iron of the proteins with heme group $\left(\mathrm{Fe}^{+2}\right.$ and $\left.\mathrm{Fe}^{+3}\right)$ [35]. The NO in the bloodstream reacts primarily with the oxyhemoglobin $\left(\mathrm{HbO}_{2}\right)$, giving rise to methemoglobin $\left(\mathrm{MetHb}^{+}\right)$and nitrite. In addition, this reaction can mediate the peroxynitrite formation, highly reactive radical. After nitrite formation, a stable subproduct of NO, is converted to nitrate and then removed from the bloodstream [29]. This dynamic may explain the reduction in NOx levels during the experiment. Once NO is formed it reacts with proteins of the erythrocytes, generating the $\mathrm{MetHb}^{+}$that is metabolized quickly and removed from bloodstream $[18,29]$. The formation of $\mathrm{MetHb}^{+}$, in this case may support the pathogenesis of the disease, since this form is unable to deliver oxygen to the organism [17].

The ROS are extremely unstable and reactive molecules able to penetrate through the cell membranes [13] and lead to several changes in proteins, lipids and DNA [10]. One of the main consequences of ROS production is lipid peroxidation, which is due to conformational change in the double and triple bonds, modifying the lipid structure [8]. These lipids are the major components of cell membranes and one of the first site for free radical attack, whereas the oxidation can cause serious injury to the cellular permeability [10]. Associated to this, the formation of iron ions in the form $\mathrm{Fe}^{+3}$ [17] may potentiate the lipid peroxidation, increasing cell damage by releasing $\mathrm{Fe}^{+2}$. The peroxides can be degraded when in contact with iron-containing molecules (hemoglobin and myoglobin) to radicals able of extracting hydrogen, such as peroxyl radical, forming the malondialdehyde as the final product of lipid peroxidation [12]. Serum TBARS levels showed an increase throughout the experiment in group 1, after $4 \mathrm{~h}$. This may have occurred as a consequence of free radicals production, inducing deleterious reactions in organic molecules [31]. In a similar study [2], evaluating nitrate/nitrite poisoning, found values of TBARS $47 \%$ higher in the poisoned group, but animals were exposed to nitrate for a long time, tending to chronicity. Taken together, our results and those reported previously indicate that the nitrate/nitrite poisoning leads to lipid peroxidation in acute form, due to free radicals production, and this process is perpetuated until the nitrate exposure remains.

The enzymatic antioxidant system evaluated in this study by CAT and SOD enzymes plays an important role in the neutralization of free radicals, preventing cell injury. SOD is specific in the removal of superoxide radical, catalyzing the reaction that will form the $\mathrm{H}_{2} \mathrm{O}_{2}$. CAT performs the $\mathrm{H}_{2} \mathrm{O}_{2}$ degradation to $\mathrm{H}_{2} \mathrm{O}$ and $\mathrm{O}_{2}$. In the presence of iron ions or in $\mathrm{H}_{2} \mathrm{O}_{2}$ excess, with antioxidant activity saturation, the hydroxyl radical is formed by Fenton reaction [8]. It is believed 
that depletion of the antioxidant activity expressed by reduction of SOD and CAT activity after four and six hours, respectively, occur as a consequence of oxidative stress triggered at the beginning of the experiment, leading to resolution of this condition and reduction of antioxidant activity. Reduction of $33 \%$ on antioxidant activity in cattle poisoned by nitrate/nitrite was described [2]. Equivalent results of the present study with a significant reduction of antioxidant activity after six hours of the experiment were observed.

\section{CONCLUSION}

Based on these results, we conclude that the nitrate and nitrite poisoning by pasture intake cultivated and fertilized with urea leads to increased levels of serum nitrite, as well as the cholinesterase activity and causes oxidative stress in cattle. It is conjectured that the cholinesterase activity and oxidative stress may assist in understanding the pathophysiology of changes caused by poisoning.

\author{
MANUFACTURERS \\ ${ }^{1}$ Sigma-Aldrich. St. Louis, MO, USA. \\ ${ }^{2}$ The R Foundation. Vienna, Austria. \\ ${ }^{3}$ IBM. Armonk, NY, USA.
}

Acknowledgments. Research supported by grants from the Conselho Nacional de Desenvolvimento Científico e Tecnológico (CNPq), No. 468602/2014-3, and Instituto Federal Catarinense (IFC), No. PJ031-2018.

Ethical approval. Research project approved by Ethical Commission on the use of Animals of the Instituto Federal Catarinense Campus Concórdia, project 16/2015.

Declaration of interest. The authors declare no conflict of interest with respect to the publication of this paper.

\section{REFERENCES}

1 Ali Z., Thomas C.L.P. \& Alder J.F. 1992. Denuder tube preconcentration and detection of gaseous ammonia using a coates quartz piezoeletric crystal. Analyst. 117(5): 899-903.

2 Al-Qudah K.M. 2010. Oxidative stress resulting from subclinical nitrite poisoning in cattle. Toxicological \& Enviromental Chemistry. 92(2): 351-358.

3 Bass D.A., Parce J.W., Dechatelet L.R., Szejda P., Seeds M.C. \& Thomas M. 1983. Flow cytometric studies of oxidative product formation by neutrophils: a graded response to membrane stimulation. Journal of Immunology. 130(4): 1910-1917.

4 Bondan C., Soares J.C.M., Cecim M., Lopes S.T.A., Graça D.L. \& Rocha R.X. 2005. Oxidative stress in the erythrocytes of cattle intoxicated with Senecio sp. Veterinary Clinical Pathology. 34(4): 353-357.

5 Boudinot E., Bernard V., Camp S., Taylor P., Champagnat J., Krejci E. \& Foutz A. S. 2009. Influence of differential expression of acetylcholinesterase in brain and muscle on respiration. Respiratory Physiology. 165(1): 40-48.

6 Carrigan M.J. \& Gardner I.A. 1982. Nitrate poisoning in cattle fed sudax (Sorghum sp. hybrid) hay. Australian Veterinary Journal. 59(5): 155-157.

7 Costagliola A., Roperto F., Benedetto D., Anastasio A., Marrone R., Perillo A., Russo V., Papparella S. \& Paciello O. 2014. Outbreak of fatal nitrate toxicosis associates with consumption of fennels (Foeniculum vulgare) in cattle farmed in Campania region (southern Italy). Environmental Science and Pollution Research. 21(9): 6252-6257.

8 Doyle R.L. 2015. Marcadores de estresse oxidativo e atividade das colinesterases em bovinos experimentalmente infectados por Babesia bovis, Babesia bigemina e Anaplasma marginale. 25f. Santa Maria, RS. Tese (Doutorado em Medicina Veterinária) - Programa de Pós-Graduação em Medicina Veterinária, Universidade Federal de Santa Maria.

9 Ellman G.L., Courtney K.D., Andres V.J. \& Featherstone R.M. 1961. A new and rapid colorimetric determination of acetylcholinesterase activity. Biochemical Pharmacology. (7): 88-95.

10 Gebicki J.M. 2016. Oxidative stress, free radicals and protein peroxides. Archives of Biochemistry and Biophysics. (595): 33-39.

11 Guevara I., Iwanejko J., Dembinska-Kiec A., Pankiewicz J., Wanat A., Anna P., Golabek I., Bartus S., MalczewskaMalec M. \& Szczudlik A. 1998. Determination of nitrite/nitrate in human biological material by the simple Griess reaction. Clinica Chimica Acta. 274(2): 177-188.

12 Halliwell B. \& Chirico S. 1993. Lipid peroxidation: its mechanism, measurement, and significance. The American Journal of Clinical Nutrition. 57(Suppl 5): 715S-725S.

13 Halliwell B., Clement V. \& Long L.H. 2000. Hydrogen peroxide in the human body. FEBS Letters. 486(1): 10-13. 
14 Housholder G.T., Dollahite J.W. \& Hulse M.T.R. 1966. Dyphenylamine for the diagnosis of nitrate intoxication. Journal of the American Veterinary Medical Association. 148(6): 662-665.

15 Ibarra G.A.T., Mayorquin A.E.R. \& Pérez M.I.G. 2013. Influence of the colinergic system on the imune response of teleost fisches: potential model in biochemical research. Clinical and Developmental Immunology. (2013). Article ID 536534: 1-9.

16 Jentzsch A.M., Bachmann H., Fürst P. \& Biesalski H.K. 1996. Improved analysis of malondialdehyde in human body fluids. Free Radical Biology and Medicine. 20(2): 251-256.

17 Jönck F., Gava A., Traverso S.D., Lucioli J. \& Furlan F.H. 2013. Intoxicação espontânea e experimental por nitrato/ nitrito em bovinos alimentados com Avena sativa (aveia) e/ou Lolium sp. (azevém). Pesquisa Veterinária Brasileira. 33(9): 1062-1070.

18 Kohn M.C., Melnick R.L., Ye F. \& Portier C.J. 2002. Pharmacokinetics of sodium nitrite-induced methemoglobinemia in the rat. Drug Metabolism and Disposition. 30(6): 676-683.

19 Kozloski G.V. 2011. Biquímica de ruminantes. 3.ed. Santa Maria: UFSM, 140p.

20 Li B., Duysen E.G., Volpicelli-Daley L.A., Levey A.I. \& Lockridge O. 2003. Regulation of muscarinic acetylcholine receptor function in acetylcholinesterase knockout mice. Pharmacology Boicheminstry and Behavior. 74(4): 977-986.

21 McCord J.M. \& Fridovich I. 1969. Superoxide dismutase. The Journal of Biological Chemistry. 244(22): 6049-6055.

22 Medeiros R.M.T., Riet-Correa F., Tabosa I.M., Silva Z.A. \& Barbosa R.C. 2003. Intoxicação por nitratos/nitritos em bovinos por ingestão de Echinochloa polystachya (capim-mandante) e Pennisetum purpureum (capim-elefante) no sertão da Paraíba. Pesquisa Veterinária Brasileira. 23(1): 17-20.

23 Mesulan M.M., Guillozet A., Shaw P., Levey A. \& Duysen E.G. 2002. Acetylcholinesterase knockouts establish central cholinergic pathways and can use butyrylcholinesterase to hidrolise acetylcholine. Neuroscience. 110(4): 627639.

24 Miranda K.M., Espey M.G. \& Wink D.A. 2001. A rapid, simple spectrophotometric method for simultaneous detection of nitrate and nitrite. Nitric oxide: Biology and Chemistry. 5(1): 62-71.

25 Nelson D.P. \& Kiesow L.A. 1972. Enthalpy of decomposition of hydrogen peroxide by catalase at $25^{\circ} \mathrm{C}$ (with molar extinction coefficients of $\mathrm{H}_{2} \mathrm{O}_{2}$ solutions in the UV). Analytical Biochemistry. 49(2): 474-478.

26 O'Hara P.J. \& Fraser A.J. 1975. Nitrate poisoning in cattle grazing crops. New Zealand Veterinary Journal. 23(4): 45-53.

27 Ozmen O. 2003. Nitrate poisoning in cattle fed Chenopodium album hay. Veterinary and Human Toxicology. 45(2): 83-84.

28 Parada R.N. 1987. Intoxicación por nitrato em bovinos lecheros em una pradera de Ballica Italiana. (Lolium multiflora var. Tama). Avances en Medicina Veterinaria. 2(1): 65-68.

29 Radi R. 1995. Reactions of nitric oxide with metalloproteins. Chemical Research in Toxicology. 9(5): 828-835.

30 Radostits O.M., Gay C.C., Blood D.C. \& Hinchcliff K.W. 2002. Doenças causadas por toxinas de plantas, fungos, cianofitas, clavibactéria e por venenos de carrapatos e animais vertebrados. In: Clínica veterinária: um tratado de doenças dos bovinos, ovinos, suínos, caprinos e equinos. 9.ed. Rio de Janeiro: Guanabara Koogan, pp.1472-1547.

31 Reuter S., Gupta S.C., Chaturvedi M.M. \& Aggarwal B.B. 2010. Oxidative stress, inflammation, and cancer: How are they linked? Free Radical Biology \& Medicine. 49(11): 1603-1616.

32 Schwertz C.I., Mendes R.E., Casagrande R.A., Lucca N.J., Couto C., Galvagni I., Stedille F.A. \& Broll F. 2014. Intoxicação espontânea e experimental de bovinos por nitrato/nitrito em pastagem de azevém (Lolium spp.). In: Anais da IV Mostra de Iniciação científica do Instituto Federal Catarinense Câmpus Concórdia (Concórdia, Brasil).

33 Tokarnia H.C., Brito M.F., Barbosa J.D., Peixoto P.V. \& Döbereiner J. 2000. Plantas tóxicas do Brasil para animais de produção. 2.ed. Rio de Janeiro: Helianthus, pp. 261-264.

34 Vali V.E.O. 2007. Hematopoietic system In: Pathology of Domestic Animals. 5th edn. vol. 3. Philadelphia: Saunders Elservier, pp.214, 260-261.

35 Vliet A., Eiserich J.P., Halliwell B. \& Cross C.E. 1997. Formation of reactive nitrogen species during peroxidasecatalyzed oxidation of nitrite. The Journal of Biology Chemistry. 272(12): 7617-7625.

36 Worek F., Mast U., Kiderlen D., Diepold C. \& Eyer P. 1999. Improved determination of acetylcholinesterase activity in human whole blood. Clinica Chimica Acta. 288(1-2): 73-90. 